\title{
"THE DIRECTION OF THE WHOLE OF THE FORCES AVAILABLE": THE DISPUTED SPHERES OF MILITARY AND CIVIL AUTHORITY IN THE EASTERN CAPE (1877- 1878), NATAL (1879) AND ZULULAND (1888)
}

\author{
John Laband \\ Wilfrid Laurier University, Canada*
}

\begin{abstract}
In the late Victorian British Empire, the spheres of authority of the civil and military powers were not unequivocally defined, and could lead to wrangles that threatened the efficient conduct of military operations. Three such disputes occurred in southern Africa between 1878 and 1888. In 1878, during the $9^{\text {th }}$ Cape Frontier War, the high commissioner replaced the Cape ministry with a more compliant one to assert control over both the imperial and colonial forces engaged. During the Anglo-Zulu War of 1879, the lieutenant-governor of Natal disputed the right of the general officer commanding to deploy African levies raised and stationed in Natal along the Zululand border. In 1888, during the uSuthu Rebellion in Zululand, the governor interfered with the general's military arrangements because he believed these arrangements affected his civil powers. To head off future disputes of this nature, the British government ruled in 1879 that the commander in the field always had to exercise full control over active operations, and in 1888 finally clarified in which circumstances the general in command assumed operational authority over both the colonial and imperial troops stationed in a colony.
\end{abstract}

Scientia Militaria, South African Journal of Military Studies, Vol 41, Nr 2, 2013, pp. 60-77.

doi : $10.5787 / 41-2-1068$

\section{Introduction}

"Her Majesty's Troops," wrote Colonel W Bellairs, Deputy Adjutant-General and commanding the Eastern Frontier in the

\footnotetext{
* The author wishes to thank Professor Stephen M Miller, the commentator, and other members of the panel at the $79^{\text {th }}$ annual meeting of the Society for Military History at Arlington, Virginia, USA, for their perceptive critique of this article and suggestions on how it could be improved
} 
Cape Colony on 19 January 1878 in a memorandum addressed to Sir Bartle Frere, Governor of the Cape and High Commissioner in South Africa, "may be said to occupy South Africa (1) for the protection of Imperial interests, and (2) to assist the Colonials, who, from weakness in numbers may be unable wholly to protect

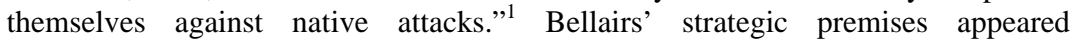
incontrovertible, but did not address the related vexed question of where the ultimate command of the troops lay. In previous articles, I have examined this issue with specific reference to the Anglo-Zulu War of 1879 and the uSuthu Rebellion of 1888 by supporters of the Zulu royal house against the newly established British administration, ${ }^{2}$ but in this study, I extended the field to the $9^{\text {th }}$ Cape Frontier War of 1877-1878 in order to put the question into fuller perspective.

The High Commissioner, confederation and the demarcation of military authority

The demarcation of military authority in southern Africa came into question from the moment the British occupied the Cape in 1806. After prolonged indecision, the imperial government decided it reposed in the hands of the High Commissioner (who was always simultaneously the Governor of the Cape Colony), and in 1846 he was designated Commander-in-Chief. ${ }^{3}$ As the imperial agent in southern Africa directly responsible to the Secretaries of State for both the Colonies and for War in London, the High Commissioner's office enabled him to assert British paramountcy over the interior of southern Africa beyond the Cape Colony, including African kingdoms and Boer republics. His authority also overrode that of governors or lieutenant governors of other British colonies in South Africa, especially in frontier matters. Therefore, as Commander-in-Chief he could claim that the framing and implementation of defence policy throughout southern Africa was his preserve alone. $^{4}$

Yet, did this mean the High Commissioner exercised actual control over all military planning and operations, or did these fell within the sphere of the General Officer Commanding Her Majesty's Forces in South Africa? That officer was himself responsible to the Secretary of State for War who framed imperial military policy and had supreme control of the army. To complicate matters further, the General Officer Commanding (GOC) was also answerable to the Field Marshal Commanding-in-Chief at the Horse Guards, who held office at the pleasure of the Crown, and who implemented the decisions of the imperial cabinet. ${ }^{5}$

This is where power of personality and local standing came into play. Because southern Africa with its relatively small imperial garrison was not a significant or highly prized military command, those nineteenth-century generals who filled the position of GOC were seldom soldiers of much renown or experience in field command, and often proved unequal to conducting operations during a real crisis. Inevitably, they leaned heavily on the High Commissioner for support and were prepared to subordinate their military authority to him. ${ }^{6}$ But then, what were the proper respective spheres of military authority when the GOC and a colonial 
governor outside the Cape (both of them effectively subordinate to the High Commissioner) came into dispute?

And there was yet another area of potential discord. In 1856, Natal was created a Colony of the Crown under a lieutenant governor with a legislative council consisting of an equal number of elected members and officials nominated by the lieutenant governor who had the casting vote. This representative form of government left real power in the hands of the lieutenant governor who answered to the Colonial Office rather than to the Legislative Council. ${ }^{7}$ That meant any dispute over military command in Natal would be a matter for the imperial officials and officers to sort out with reference to their superiors in London, and not for the Legislative Council.

In the Cape Colony it was different. There, with steeply rising revenues resulting from the discovery of diamonds in 1868 and a boom in wool and ostrich feather exports, it was clearly possible for the colonists to bear the financial burden of self-government. Responsible government was duly instituted in June 1872. Henceforth, the Governor of the Cape would have to work with a prime minister and his cabinet responsible to the elected Legislative Assembly.

It was not only a vociferous faction of colonists under the leadership of JC Molteno, the member for Beaufort West (who became the first prime minister of the Cape in 1872) that was eager for responsible government. William Gladstone's economising first Liberal ministry (1868-1874) also urged responsible government in the belief that the Cape would henceforth pay for its own defence and administration and relieve the imperial government of the burden. More than that, it was envisaged that a self-governing Cape, as the richest political community in southern Africa, would take the lead in confederating the other British colonies, Boer republics and African-ruled territories of southern Africa under British paramountcy. In that way, the endemic, expensive wars of the region would be brought to an end, and a prosperous, stable potential dominion established at the strategically vital tip of Africa able to manage its own affairs and shoulder its own defence. Benjamin Disraeli, the Earl of Beaconsfield's second Conservative ministry (1874-80) enthusiastically embraced this vision. The South Africa Act of 1877, also known as the Permissive Federation Bill, provided the constitutional framework for confederation which the Colonial Secretary, Lord Carnarvon, ordered the new High Commissioner, Sir Bartle Frere, to implement. ${ }^{8}$

To forward the confederation project, however, Frere and Molteno had to work hand in hand. But Frere, a seasoned proconsul of empire used to getting his own way, soon came to perceive that the Molteno ministry did not share his imperial vision. And, undoubtedly, Molteno was morbidly suspicious of British interference in the newly self-governing colony's affairs. He particularly resented the colony having to pay for the upkeep of the British garrison at the Cape which he realised was being maintained to further the confederation project beyond the colony's borders. $^{9}$ 


\section{The $9^{\text {th }}$ Cape Frontier War and the dispute over divided military command}

The simmering differences between the Governor and his Prime Minister came to the boil with the outbreak of the $9^{\text {th }}$ Cape Frontier War in late $1877 .{ }^{10}$ After a hundred years of conflict in the Cape eastern frontier region fuelled by white settlers thrusting into the lands of the Xhosa chiefdoms, the borderlands were still in bitter contention. In August 1877, the Gcaleka Xhosa to the east of the Kei River (which nominally marked the border) rose up in arms. Since this was in territory beyond the Cape frontier, the conduct of the war was Frere's responsibility as High Commissioner. But to wage a campaign he required Cape logistical and military support. He agreed with Molteno and John X Merriman, the Commissioner of Crown Lands and Public Works (and in practice the Cape minister of defence), that it was the self-governing Colony's duty to protect its own border, even though he was sceptical of the Cape's military ability to do so.

In September 1877, Frere and Merriman set up their headquarters at King William's Town in the Ciskei to the west of the Kei border. Colonel Charles Griffith, the Cape government agent in Maseru in Basutoland, was appointed on 26 September 1877 to command the Colonial Frontier Armed and Mounted Police, settler volunteers and Mfengu levies who were to campaign against the Gcaleka in the Transkei. Col. Richard Glyn was put in command of the imperial troops who were to garrison the military posts established east of the Kei River to protect the Cape frontier and to hold open the line of communication. Lt Gen. Sir Arthur Thurlow Cunynghame, GOC of the Cape since 1874, took formal command on 2 October 1877 of all the troops, imperial and colonial.

By November 1877, Griffith's campaign seemed to have succeeded when the Gcaleka retired east across the Mbashe River. But it was only a ploy, and on 2 December, the Gcaleka returned in force and were soon joined in arms by the Ngqika Xhosa who lived on a large reserve in the Ciskei on the outskirts of King William's Town itself. Panic swept across the settler communities of the eastern frontier. Frere had no doubt that the undisciplined colonial forces did not possess the military capability to contain the crisis, a view shared by Cunynghame who in his memoirs described their best units as miserably mounted, indifferently clothed, and wretchedly armed and equipped. ${ }^{11}$ This, then, was not a time to consider colonial sensitivities, and on 8 December Frere placed Cunynghame in active command of the imperial troops, which he sent into the Transkei to deal with the Gcaleka. At the same time he placed Cunynghame in direct command of the colonial troops which he pulled back to put down the Ngqika revolt in the Ciskei.

Molteno arrived at headquarters in King Williams Town from Cape Town on 8 January 1878 , and was very unsatisfied with Frere's military dispositions. He had no faith in British as opposed to colonial troops because he believed the former to be slow, clumsy, unnecessarily costly and unsuited to local conditions. Moreover, he discovered that Merriman had developed a real antipathy to Cunynghame whom 
he found over-cautious as a commander and an unbearable old chatterbox to boot. Above all, both men were determined to prevent Frere from interfering with colonial self-government, and this included full responsibility for defence. ${ }^{12}$

What Molteno and Merriman did not realise was that Cunynghame, abetted by Col. Bellairs, was pressing Frere urgently for imperial reinforcements, not only for the Cape campaign, but also to stabilise the situation on the borders of Natal and the Transvaal Territory. ${ }^{13}$ Frere required little prodding. On 31 December 1878 he wrote to Carnarvon, strongly requesting that two regiments be sent out immediately to the Cape as a reinforcement or a relief for the regiments slated to return home, and that a battery of field artillery accompany them for service in the Cape, Natal and Transvaal. ${ }^{14}$ The Colonial Office responded with the immediate despatch of a regiment because Carnarvon feared for the confederation project if the unfavourable situation along the borders of the Cape encouraged African rulers abutting Natal and the Transvaal. Carnarvon nevertheless made clear that he was severely disappointed that the Cape had proved unable to shoulder its military burden as a self-governing colony. He consequently made it an "imperative condition" that the colonial government must make monthly payments into the Treasury Chest to cover the cost of supplying troops in the field. ${ }^{15}$

Meanwhile, unaware that imperial reinforcements were to be sent out, Molteno was engaged in lengthy, stormy meetings with Frere over Cunynghame's sole command over all the forces on the Cape frontier. On 11 January, Molteno insisted that the colonial forces should undertake their own independent military campaign in the Ciskei under Griffith's separate command, and duly appointed him Commandant General on the $15^{\text {th }} \cdot{ }^{16}$ Molteno made it insultingly clear to Frere that "the burgher forces would not willingly submit to military control, nor cordially cooperate with regular troops; that they would only act and fight in their own way and under their own leaders". ${ }^{17}$ However, Bellairs entertained no doubt that Molteno's motives were entirely political and informed the Secretary of State for War (SSW) so, ${ }^{18}$ as did Frere Carnarvon on 24 January. In the same despatch, Frere deplored Molteno's principle of two separate commands in the same area of operations and made the point that "without staff or military experience" Commandant Griffith was unlikely "to organise effectively the incongruous materials at his command". The consequences of Molteno's "totally uncalled for interference with the General's proceedings at the eleventh hour" would, he direly predicted, "imperil" the entire campaign. $^{19}$

Frere returned to the attack in a voluminous despatch to Carnarvon on 30 July, lamenting that he had been unable to persuade Molteno that "two independent generals commanding in the same field is not only a professional but a practical impossibility", and waxing indignant that Merriman (the Commissioner of Crown Lands) was acting "in ostentatious disregard of all authority of the Governor and Commander of the Forces as a kind of minister at war and general commanding in the field ... without professional knowledge or any professional staff". ${ }^{20}$ Cunynghame also cautiously weighed in, informing the Secretary of State for War 
that "the Civil Government has taken upon itself the conduct of military operations over a large area of country within my command" but declining to state his own opinion as the issue of the divided command was properly a matter for the High Commissioner. $^{21}$

This indeed was the crux of the matter, for Molteno was effectively denying Frere's authority over the Cape forces. Frere strongly believed otherwise, and as he later wrote in defence of the drastic course of action he adopted against the Molteno ministry:

It is, I believe, the constitutional duty of the Governor and Commander-in-Chief to guard against such a dangerous anomaly as a divided command of military forces...in one area of operations; and, if ministers insisted on such a divided command, it should, I believe, be the Governor's duty to prevent, by all constitutional means in his power, their imperilling the safety of the by any such division of authority and responsibility. ${ }^{22}$

Yet more was at stake than the constitutional question of where the command of the Colonial troops lay. Molteno had learned of Frere's request for reinforcements and bluntly refused to pay for them as he contended the colonial troops were sufficient for the current campaign. Besides, he and his ministers were appalled that Frere had proceeded without prior consultation. ${ }^{23}$ Frere and Cunynghame remained adamant that the reinforcements were required both to defend the Colony and to implement the wider confederation policy, with Frere going so far as to insist that he would be "fitter for a lunatic asylum" than governor if he thought otherwise. ${ }^{24}$ At their meeting on 31 January, Molteno refused to back down, and Frere finally determined to have done with his ministers. ${ }^{25}$

\section{The dismissal of the Cape ministry and vindication of the High Commissioner's military authority}

Molteno and Merriman belligerently refused to resign as they insisted they were accountable only to parliament, so Frere dismissed the ministry on 6 February. ${ }^{26}$ Merriman wrote angrily to his father that "the Governor in the exercise of his very arbitrary prerogative has thought fit to dismiss his ministers", an action which "does away with any kind of safeguard which Responsible Government was supposed to confer, for it is manifest that a Governor ... can dismiss his minsters at will". ${ }^{27}$

But Frere was quite unrepentant. Earlier he had written Molteno that the "dictates of common sense" assigned "the direction of active military duties to active military men on the principle of every man to his own business", ${ }^{28}$ and now Cunynghame rejoiced that the "sort of Military Dictatorship" which the Cape ministers had delegated to Merriman, and which he had exercised in defiance of Frere's authority, was over. ${ }^{29}$ 
Back in London, the War Office entertained no hesitation condemning the divided command at the Cape and pouring scorn on the inadequacy of the Colonial troops. It wasted no time in informing the Colonial Office that it believed "disastrous results" would likely follow. ${ }^{30}$ The Colonial Office took immediate heed, and came down firmly on the side of Frere against the Molteno ministry. In his minute of 1 March, Under-Secretary Malcolm could find no fault with Frere's freeing himself of his recalcitrant ministers, and was totally damning of Molteno and Merriman "whose conduct is no doubt to be explained to a great extent by the combination of ignorance \& arrogance wh (sic) actuates them and the responsible ministers of the Colony". He contemptuously concluded that the "notion of conducting separate \& independent operations on either side of a small river traversable by the enemy is ridiculous even to one not a soldier". Malcolm went on to lay down that the -

Colony must be made to say at once whether they want the assistance of H.M.'s forces or not. If they decline their help, they must ... be prepared to pay for them, and must leave the conduct of military operations in their hands. If they do not want them they must at whatever risk to the Colony be withdrawn. ${ }^{31}$

The Colonial Office was quick too to uphold the constitutionality of Frere's dismissal of his responsible ministers and his appointment of new ones in their place, even though no precedent in self-governing colonies had been established for doing so. ${ }^{32}$ The position adopted was that responsible ministers "hold office during pleasure, and the Governor has, under the Letters Patent power to appoint and remove all such officers". 33

In Cape Town, Frere appointed the prominent eastern frontier politician, J Gordon Sprigg, prime minister. Sprigg made it his first priority to coordinate military operations once more ${ }^{34}$ and the Colonial Office rewarded him for his efforts to organise a more effective system of defence by recognising the strains on the Cape treasury and not continuing to press for payment for the imperial troops. ${ }^{35}$ The sacking of Molteno's ministry had caused a great stir, but Frere and his ministers won the ensuing propaganda war even before parliament reconvened in May $1878 .{ }^{36}$ Frere could triumphantly report on 18 June that parliament had voted to approve his dismissal of the Molteno ministry and to uphold the authority of the High Commissioner "as constitutional head of all armed forces of the Colony". 37 Sir Michael Hicks Beach, who had succeeded Lord Carnarvon in February as Colonial Secretary, conveyed his "warm approval" of Frere's conduct and his government's official thanks. ${ }^{38}$

An observer had noted in March 1878 that Frere "shewed traces of the severe strain he had been undergoing for several months past", ${ }^{39}$ but at least he was soon to be fully vindicated. The unfortunate Cunynghame, on the other hand, who prided himself on unfailingly employing his "utmost diligence" in carrying out 
Frere's military policy, ${ }^{40}$ found himself being offered up as a placatory sacrifice to appease ruffled colonial opinion. On 4 March 1878 Maj. Gen. Frederic Thesiger (who succeeded as Baron Chelmsford in October 1878) arrived at headquarters and superseded Cunynghame in command of the troops in the Cape, Natal, Transvaal and St. Helena with the local rank of Lt Gen. ${ }^{41}$ Cunynghame understood well enough that he was being deprived of his command in favour of a junior officer for "want of cordiality with the ministry", a ministry which had itself been summarily dismissed. He could not but consider himself cruelly humiliated before his astonished troops, and it was no consolation that the Duke of Cambridge himself assured him that he had committed "no fault whatsoever". ${ }^{42}$ His military career was over, and being made Knight Grand Cross of the Order of the Bath (GCB) in June 1878 was an empty honour and scant consolation. As for the upstart Thesiger, he could boast that with the approval of Sprigg's ministry he would soon enjoy "the entire direction of the Colonial as I have already of the Imperial troops". 43

The Anglo-Zulu War and the dispute over the command of the Natal border levies

With the conclusion of the $9^{\text {th }}$ Cape Frontier War, Thesiger (now Chelmsford) proceeded to Natal to prepare for the Zululand campaign which Frere was set upon as the next step in his consolidation of confederation. There he discovered that what pertained in one colony did not necessarily follow in another, and to his intense chagrin, he would soon find himself embroiled in his own dispute with the colonial authorities over military command.

The Lieutenant Governor of Natal (Governor after 1882) had at his disposal as Commander-in-Chief and Vice-Admiral in and over Natal (and after 1887 of Zululand as well), a number of small colonial mounted units. In addition, as supreme chief over the native population, he had the right to exact isibhalo - or compulsory labour and military service - from Africans living in the colony. In time of military need, therefore, magistrates (as the Governor's representatives) were authorised to raise levies from the chiefs in the native reserves and place them under white levyleaders. $^{44}$

The most contentious issue concerning command in the Anglo-Zulu war of 1879 centred on the deployment and command of the Natal border levies. In December 1878, Chelmsford and Sir Henry Bulwer, the Lieutenant Governor, agreed that in the three Colonial Defensive Districts along the Natal border with Zululand, the commander would raise a small standing Border Guard supplemented by a larger reserve who would relieve each other at intervals. ${ }^{45}$ On the eve of the invasion of Zululand in January 1879, these Defensive Districts were placed under Chelmsford's military command, and Bulwer accepted that Chelmsford had the right to dispose of the colonial troops stationed there as he saw fit. ${ }^{46}$

Following the Isandlwana disaster and his retirement into Natal to regroup, Chelmsford insisted that border levies should assist by making diversionary raids 
across the border into Zululand, ${ }^{47}$ undertaking what he termed the "active defence". ${ }^{48}$ Bulwer refused permission for them to do so. As he saw it, the border levies had been raised solely to protect Natal from Zulu attack, ${ }^{49}$ and "no provision is made for the supersession of the Lieutenant-Governor by any military or other authority". ${ }^{50}$ His own Attorney General, Michael Gallway, did not support him, giving his opinion on 14 March 1879 that it was Chelmsford's right to direct Natal's Africans to perform "any military service which the General Commanding in Chief may assign to them or order them to engage in". 51

Frere had proceeded to Natal in late September 1878 to oversee the preparations for the Zulu campaign, and as High Commissioner and Commander-inChief it should have been up to him to resolve the dispute. He agreed with Bulwer that the raw border levies should be reserved entirely for the "passive defence" within Natal's borders, ${ }^{52}$ but he also believed that military considerations should take precedence in the area of operations. However, his credit and prestige had been fatally damaged by the Isandlwana disaster, and he drew back from intervening aggressively as he had in the Cape in 1878 to resolve the issue of divided command. His sights were in any case set on the Transvaal Territory where far more important problems were brewing. There the irreconcilable Boers were agitating against the British annexation of 1877 and were seeking to regain their independence. On 15 March 1879, Frere left Natal to negotiate directly with them. ${ }^{53}$ He was pursued by letters from Bulwer and Chelmsford, the General vehemently insisting that "the danger of divided command ... be done away with". ${ }^{4}$

But Frere proposed nothing concrete to keep the peace between them. Bulwer consequently turned to his superiors in the Colonial Office, complaining at excessive length to Sir Michael Hicks Beach that Chelmsford, by ordering the levies into Zululand, had "exceeded his powers and acted without due regard for the authority of this Government". ${ }^{55}$ For his part, Chelmsford wrote to the Commanderin-Chief, the Duke of Cambridge, complaining that Bulwer's interference with his military arrangements was "quite indefensible", and requesting the Field Marshal's full support. ${ }^{56}$

\section{The general's command over all forces in the field confirmed}

The imperial government at length responded, and on 19 May 1879, Hicks Beach made known that it had decided that the "full command of any forces, whether European or Native ... must of course be with the General, with whom the responsibility for the operation rests". ${ }^{57}$ As it had in the Cape the previous year, the victory had gone to the military. But it was not an unequivocal one. The exasperated government also decided to put a final end to the embarrassing dispute by creating a single, unified South African command. On 28 May, the chief civil and military authority in south-east Africa was placed into the hands of Gen. Sir Garnet Wolseley who would outrank Chelmsford as full general, subordinate Bulwer as Governor of Natal and displaced Frere as Governor of the Transvaal and High Commissioner for South East Africa. ${ }^{58}$ Chafing at his supersession, Chelmsford resigned his command 
on 5 July 1879 and retired to England to face his many critics and to live out the rest of his life as a purely ornamental soldier and courtier. ${ }^{59}$ Frere was finally recalled by mid-1880. He never recovered from his humiliation, although he was too resilient to have died of a broken heart as was said of him at his death in $1884 .{ }^{60}$

It might be that the cabinet directive of 19 May 1879, which laid down that full command of ALL forces had to be with the general responsible for operations, was both clear and unambiguous. Yet, events in Zululand during 1888 would prove otherwise, and demonstrate how easily even cabinet decisions can be forgotten.

\section{The uSuthu Rebellion and the dispute between the military and civil authorities}

Zululand became a British possession as from 18 May 1887. Sir Arthur Havelock, since February 1886 already Governor of the Colony of Natal, was in addition appointed Governor of Zululand with the "powers and prerogatives of Supreme Chief over the African people of the territory". ${ }^{61}$ This gave him the right, as in Natal, to raise African levies and auxiliaries in time of military need. That moment was soon upon him, for by late April 1888, the disgruntled heir to the last Zulu king and his royalist faction, the uSuthu, were in open rebellion. The civil officials in Zululand and their inadequate armed forces rapidly lost control of the northern half of the new colony. ${ }^{62}$ A conventional military solution had become essential, and on 28 June 1888, Lt Gen. Henry Augustus Smyth, RA, who had been appointed to the Cape of Good Hope: South African Command on 23 January 1888 from his previous posting as Commandant of the Woolwich Garrison, assumed command of the troops in Zululand. ${ }^{63}$

He immediately proposed that he "be given the direction of the whole of the forces available" without having to keep his regular troops "in attendance" on the movements of other, colonial forces under the separate command of Zululand officials responsible to Havelock. ${ }^{64}$ This certainly seemed in line with the cabinet decision of 19 May 1879 giving full command of the forces to the general in charge of operations. Havelock, however, was determined that the troops operating in Zululand should be no more than an adjunct to the forces of the civil powers, providing the necessary military support only if called upon for assistance by officials enforcing the law and arresting the rebels. ${ }^{65}$ This amounted to a divided command over the forces deployed in Zululand, made worse by Havelock's practice of bombarding Smyth almost daily with instructions on operational matters. ${ }^{66}$

Sir Hercules Robinson, who was High Commissioner from 1880 to 1890 , seems to have taken no part in this tussle over command, which neither Smyth nor Havelock was willing to concede without a fight. Smyth laid down that operational and tactical decisions were his, not the Governor's. ${ }^{67}$ Havelock responded by insisting that in the matter of civil and military relations, he was "complying strictly" with the regulations in Chapter 2 of the Colonial Rules and Regulations. ${ }^{68}$ But with the precedent of the Molteno-Cunynghame and Bulwer-Chelmsford disputes doubtlessly in mind, Smyth believed he had right on his side. On 17 July 
1888, he appealed directly to the Secretary of State for War, the Hon. Edward Stanhope, complaining (as had Cunynghame and Chelmsford before him) of the delay to military operations caused by the subordination of the military to the civil authority. ${ }^{69}$

Stanhope tried diplomacy while Smyth continued to fulminate, but Havelock would not budge. ${ }^{70}$ Yet, clear as it must have become to the authorities in London that a real crisis in military-civil relations had arisen in Zululand, comparable to those in 1878 and 1879, no immediate attempt was made to resolve it before the campaign had run its course by September and Smyth had departed for Cape Town. $^{71}$

\section{The relationship between civil and military authorities in a colony defined}

But soon after the war was over, the imperial cabinet did address itself to the matter, and on 1 November 1888, Ralph Thompson, the Under-Secretary of State at the War Office, communicated its recommendations to the Colonial Office. ${ }^{72}$ Vindicating Smyth (as both Cunynghame and Chelmsford had been), it laid down that once a general had been told to "go on", then military operations became his full responsibility. If relations between the civil and military authorities subsequently broke down, the governor would consequently be to blame for not restricting himself to the civil sphere. To ensure compliance, pages 304-5 of the Colonial List 1888: Rules and Regulations were to be amended to clarify the relationship between Colonial governors and officers commanding troops in the field. The relevant paragraphs now read as follows:

11. Except in the case of invasion or assault by a foreign enemy, it is the duty of a governor to determine the objects with which and the extent to which HM's Troops are to be employed. He will therefore issue the Officer in Command of the Forces directions respecting their distribution and employment ...

13. On the other hand, the Officer in command of the Forces will determine all military details respecting the Distribution and Movement of Troops ... in conformity with the general directions issued to him by the Governor ...

18. And in the event of the Colony ... becoming the scene of active military operations, the Officer in Command of HM's Land Forces assumes the entire military authority over the Troops. ${ }^{73}$

These clarified regulations made good sense, and restricted the civil and military authorities to their proper spheres of competence. Lord Knutsford, the Colonial Secretary, could only agree with Thompson's proposed modifications, and on 4 January 1889 wrote to Thompson accepting them. ${ }^{74}$ 
Nevertheless, in the light of the repetition of the same military-civilian dispute in 1877-1878, 1879 and 1888 and of its identical outcome each time in favour of undivided military command, it comes perhaps as no surprise that in the build-up to the Anglo-Boer War in 1899, there was again a flurry of correspondence before Natal (which had enjoyed responsible government since 1893) accepted that military planning for the coming campaign had to take precedence over parochial requirements. ${ }^{75}$ During the war, Lord Kitchener placed Natal's Province of Zululand under martial law on 25 March 1901, precisely to ensure the military cooperation of the reluctant local officials. ${ }^{76}$ It seems that in the late Victorian British Empire in southern Africa, independently minded civic colonial authorities were never readily or easily prepared to subordinate themselves to imperial military command, regardless of how often their pretensions were rebuffed.

\section{Endnotes}

${ }^{1}$ The National Archive, Kew (hereafter NA), War Office Papers (hereafter WO) 32/7680: Memorandum, Col. W Bellairs to Sir Bartle Frere, 20 January 1878 .

${ }^{2}$ Laband, J. "Bulwer, Chelmsford and the border levies: The dispute over the defence of Natal". In Laband, J \& Thompson, P (eds), Kingdom and colony at war: Sixteen studies on the Anglo-Zulu War of 1879, Pietermaritzburg and Cape Town: University of Natal Press and N \& S Press, 1990, 150-165; Laband, J. “'The danger of divided command': British civil and military disputes over the conduct of the Zululand campaigns of 1879 and 1888". Journal of the Society for Army Historical Research 81/328. 2003. 339-355.

${ }^{3}$ See Sir Henry Pottinger's High Commission of 10 October 1846 [Royal Sign Manual and Signet] quoted in Benyon, J. Proconsul and paramountcy in South Africa: The High Commission, British supremacy and the subcontinent 1806-1910. Pietermaritzburg: University of Natal Press, 1980, 353, Appendix A.

${ }^{4}$ Harlow, VT. "Cape Colony, 1806-1822”. In Walker, EA (gen ed), The Cambridge history of the British Empire, Volume VIII: South Africa, Rhodesia and the High Commission territories, Cambridge: Cambridge University Press, 1963, 206-208; Benyon op. cit., pp. 7-11, 69-70, 212-213, 253-256 (Appendix A: Commissions illustrating the growth and closer definition of powers, 1846-1885), 358-359 (Appendix B: Diagram of the structure of imperial government).

${ }^{5}$ Spiers, E. The late Victorian Army 1868-1902. Manchester: Manchester University Press, 1992, 17-18, 22-23.

${ }^{6}$ Beckett, I. The Victorians at war. London: Hambledon, 2003, 95-96. 
${ }^{7}$ Verbeek, J, Nathanson, M \& Peel, E (comps). Webb's guide to the official records of the Colony of Natal (expanded and revised ed). Pietermaritzburg: University of Natal Press, 1984, xix.

${ }^{8}$ De Kiewiet, CW. "The establishment of responsible government in Cape Colony, 1870-187'. In Walker op. cit., pp. 452, 455, 458; Walker, EA. History of southern Africa. London: Longmans, 1968, 343; Davenport, TRH. South Africa: A modern history. Johannesburg: Macmillan, 1977, 78-79.

${ }^{9}$ Lewsen, P (ed). Selections from the correspondence of JX Merriman 1870-1890. Cape Town: Van Riebeeck Society, 1960, 26; Gon, P. The road to Isandlwana. Johannesburg: Ad. Donker, 1979, 107.

${ }^{10}$ For useful summaries of the $9^{\text {th }}$ Cape Frontier War as they affected the question of command, see Lewsen, P. John X Merriman: Paradoxical South African statesman. New Haven: Yale University Press, 1982, 65-68; Lewsen op. cit., pp. 26-7; Hummel, C (ed). The Frontier War journal of Major John Crealock ( $2^{\text {nd }}$ series, no. 19). Cape Town: Van Riebeeck Society, 1989, 1011.

${ }^{11}$ Cunynghame, Sir AT. My command in South Africa. London: Macmillan, 1880, 49, 307.

12 Lewsen, P. "The first crisis in responsible government in the Cape Colony". Archives Year Book V/ii. 1943. 242-245; Lewsen, Selections from ... op. cit., p. 66; Hummel op. cit., p. 12.

13 British Parliamentary Papers (hereafter BPP (C. 2000), enc. 6 in no. 78: Cunynghame to Frere, Ibeka, 29 December 1877. See also BPP (C. 2000), enc. in no. 27: Cunynghame to Secretary of State for War (G Gathorne Hardy), King William's Town, 12 December 1878; NA, WO 32/7680: Memorandum from Bellairs to Frere, 20 January 1878.

${ }^{14}$ BPP (C. 2000), no. 78: Frere to Carnarvon, 31 December 1878 (recd. 5 Feb 1878).

15 National Army Museum, Chelsea (hereafter NAM), Chelmsford Papers (henceforth CP) 12: Cape of Good Hope. Copy of despatches which have passed between the Right Honourable the Secretary of State for the Colonies and His Excellency the Governor since January last. Printed by order of the House of Assembly. Cape Town: Saul Solomon, 1878 (hereafter Cape of Good Hope), 11-12: Cape of Good Hope no. 482: Carnarvon to Frere, 30 January 1878. See also BPP (C. 2000), no. 46: JC Vivian to Under-Secretary of State for War [Ralph Thompson], 22 January 1878.

${ }^{16}$ Molteno fully laid out his principle of "separating the Command and direction of Colonial Forces, from that of Her Majesty's troops" in a long memorandum 


\footnotetext{
dated 19 January 1878 (NA, WO 32/7680: Copy of Molteno's memorandum).

${ }^{17} B P P$ (C. 2079): Frere to Carnarvon, King William's Town, 16 January 1878 (recd. 16 Feb 1878).

${ }^{18}$ NA, WO 32/7678: Bellairs to Gathorne Hardy, 16 January 1878.

${ }^{19}$ BPP (C. 2079), no. 42: Frere to Carnarvon, 24 January 1878 (red. 1 March).

${ }^{20}$ NA, WO 32/7683: Frere to Carnarvon, 30 January 1878.

${ }^{21}$ NA, WO 32/7680: Cunynghame to Gathorne Hardy, 30 January 1878.

${ }^{22}$ BPP (C. 2079), no. 86: Frere to Sir Michael Hicks Beach 21 May 1878 (recd. 14 June).

${ }^{23}$ NA, CO 48/485, Cape 1782, minute, 13 February 1878; JX Merriman to Mrs J Merriman (mother), 25 February 1878, in Lewsen, Selections from ... op. cit., p. 42.

${ }^{24}$ Cape of Good Hope, 5: Minute from the Governor in Answer to Minute of $\mathrm{Mr}$ Molteno, dated 2 February 1878, 6 February 1878; BPP (C. 2079), enc. 2 in no. 86: Cunynghame to Frere, 3 February 1878.

${ }^{25}$ Lewsen, Selections from ... op. cit., 69, 73; Lewsen, "The first crisis ..." op. cit., p. 250; BPP (C. 2079), enc. in no. 86: Memorandum by Frere on Molteno's memoranda of 19 and 22 January 1878, 26 January 1878.

${ }^{26} B P P$ (C. 2079), enc. in no. 86: Minutes of Executive Council, King William's Town, 2 February 1878, BPP (C. 2079), no. 54: Frere to Carnarvon, 5 February 1878 (recd. 11 March 1878); BPP (C. 2079), enc. 2 in no. 86: Frere to Secretary of State for Colonies, 5 February 1878; BPP (C. 2079), enc. in no. 63: Frere to Molteno and Merriman, 6 February 1878; BPP (C. 2079), no. 63: Frere to Secretary of State for Colonies, 12 February 1878 (recd. 15 March).

${ }^{27}$ JX Merriman to his father, Bishop NJ Merriman, 19 February 1878, in Lewsen, Selections from ... op. cit., pp. 40-41; Mrs Agnes Merriman (JX's wife) to Mrs J Merriman (his mother), 19 February, 1878: "You will I know be shocked to hear that Sir Bartle whom we thought so good and pious has behaved most scandalously and in a most un-Christianlike manner" (Lewsen, Selections from ... op. cit., pp. 38.

${ }^{28}$ Cape of Good Hope, 5: Minute from the Governor in Answer to Minute of $\mathrm{Mr}$ Molteno, dated 2 February 1878, 6 February 1878.

${ }^{29}$ NA, WO 32/7680: Cunynghame to Gathorne Hardy, 13 February 1878.

30 NA, WO 32/7678; Minute, Secretary of State for War to Mr JC Vivian, 16 February 1878. See also BPP (C. 2079), no. 25: Ralph Thompson to Vivian to Under-Secretary of State in the Colonial Office, 23 February 1878; NA,
} 
WO 32/7680: Minute, Assistant Under-Secretary of State in the War Office to Under-Secretary of State in the Colonial Office, 27 February 1878.

${ }^{31}$ NA, Colonial Office Papers (henceforth CO) 48/485, Cape 2672, minute by $\mathrm{Mr}$ Malcolm, 1 March 1878.

${ }^{32}$ NA, CO 48/485, Cape 3144: Minute by Mr Malcolm, 15 March 1878.

${ }^{33}$ NA, CO 48/485, Cape 3144: Minute by Lord Cranborn, 16 March 1878.

${ }^{34} B P P$ (C. 2100), no. 56: Frere to Hicks Beach, 16 March 1878, quoting from Sprigg's semi-official letter of 27 February 1878. See also NA, WO 32/7680: Cunynghame to Gathorne Hardy, 13 February 1878.

${ }^{35} B P P$ (C. 2100), no. 66: RH Meade, Colonial Office, to Secretary to the Treasury, 29 April 1878.

${ }^{36}$ See, for example, the report in the Cape Argus of 12 February 1878 saying that it had been "nothing short of madness to cast aside the only military organisation in the country". Frere laid before parliament the papers relating to the dispute sufficient to explain dismissing Molteno's ministry and allowed only Sprigg and his ministers to see the confidential papers. (BPP (C. 2079): Frere to Hicks Beach, 14 May 1878.)

${ }^{37} B P P$ (C. 2144), no. 101: Frere to Hicks Beach, 18 June 1878.

${ }^{38} B P P$ (C. 2144), no. 119: Hicks Beach to Frere, 25 July 1878.

${ }^{39}$ Hummel, Crealock 20: Crealock's Dairy, 4 March 1878.

${ }^{40}$ NA, WO 32/7680: Cunynghame to Gathorne Hardy, 30 January 1878.

${ }^{41} B P P$ (C. 2100), no. 56: General Order King William's Town, 11 March 1878, Col. Bellairs.

42 BPP (C. 2144), enc. 1 in no. 102: Memorandum by Cunynghame, HMS Hamalaya, at sea, 4 April 1878; NAM, Cunynghame Papers 7805-42: Memorandum by Cunynghame, Queen Anne's Mansions, Westminster, 6 May 1878.

${ }^{43}$ BPP (C. 2100), enc. in no. 43: Gen. Thesiger to Secretary of State for War, 12 March 1878.

44 Laband, J \& Thompson, P. The illustrated guide to the Anglo-Zulu War. Pietermaritzburg: University of Natal Press, 2000, 22-23.

45 Pietermaritzburg Archive Repository (henceforth PAR), Government House papers (henceforth GH) 1413: no. 4909/78: Bulwer to CBH Mitchell, 20 December 1879; PAR, GH 1326, no. 160/78: Chelmsford to Bulwer, 30 December 1878.

${ }^{46}$ PAR, GH 1326, no. 6/79: Bulwer to Chelmsford, 13 January 1879; PAR, Colonial Secretary's Office, Natal papers (henceforth CSO) 1926, no. 1356/79: Bulwer to Chelmsford, 28 February 1879. 
${ }^{47}$ PAR, GH 1423, enc. in no. 1222/79: memorandum by Chelmsford, 20 February 1879.

${ }^{48}$ BPP (C. 2318), no. 18: Chelmsford to Bulwer, 18 April 1879.

${ }^{49} B P P$ (C. 2318), enc. 19 in no. 1: extracts from the proceedings of the Natal Executive Council, 1 March 1879.

${ }^{50}$ BPP (C. 2318), enc. 7 in no. 1: Bulwer to Chelmsford, 7 February 1879.

${ }^{51}$ PAR, Attorney-General's Office 1/16/1, p. 405: memorandum by MH Gallwey, 14 March 1879.

${ }^{52} B P P$ (C. 2318), enc. 10 in no. 1: minute by Frere, 11 February 1879.

${ }^{53}$ Worsfold, B. Sir Bartle Frere: A footnote to the history of the British Empire. London: Thornton Butterworth, 1923, 194; Laband, J. The Transvaal Rebellion: The First Boer War 1880-1881. London: Pearson Longman, 2005, 20-22.

${ }^{54}$ Chelmsford to Frere, 21 April 1879, quoted in French, Maj. the Hon. G. Lord Chelmsford and the Zulu War. London: John Lane, 1939, 212-213; PAR, GH 1221, no. 67/79: Bulwer to Hicks Beach, 16 April 1879.

${ }^{55}$ PAR, GH 1221, no. 67/79: Bulwer to Hicks Beach, 16 April 1879.

${ }^{56}$ NAM, CP 28: Chelmsford to Duke of Cambridge, 11 April 1879.

${ }^{57}$ BPP (C. 2318), no. 11: telegram, Hicks Beach to Bulwer, 19 May 1879.

${ }^{58}$ BPP (C. 2318), no. 19: Hicks Beach to Bulwer, 28 May 1879; BPP (C. 2318): Appendix: Commission issued to Sir Garnet Wolseley, 28 May 1879.

${ }^{59}$ Laband, J. "'Lord Chelmsford”. In Corvi, SJ \& Beckett, IFW (eds), Victoria's generals, Barnsley: Pen \& Sword, 2009, 116-118.

${ }^{60}$ Worsfold op. cit., p. 335.

${ }^{61}$ NA, Colonial Office 879/30, African Confidential Print 370, enc. 1 in no. 11: Havelock to Lt-Gen. HA Smyth, 29 June 1888; BPP (C. 5143), enc. in no. 29: Proclamation of the Annexation of Zululand, 14 May 1887; PAR, Government House, Zululand (henceforth GHZ) 845: Secretary of State to Special Commissioner Zululand, 11 May 1887; PAR, Zululand Archives (ZA) 5, no. R595/87: Havelock to Melmoth Osborn, 21 June 1887; PAR, GHZ 845: Governor of Natal to Secretary of State, 22 June 1887.

${ }^{62}$ For British military operations in Zululand during 1888, see Laband, J. The atlas of the later Zulu Wars 1883-1888. Pietermaritzburg: University of Natal Press, 2001, 87-116, passim.

${ }^{63}$ Lee, Sir S (ed). The dictionary of national biography: Supplement, January 1901 - December 1911. Oxford: Oxford University Press, 1920, vol. II, 352-353.

${ }^{64}$ PRO, WO 32/7838, file 079/6889: Smyth to Havelock, 30 June 1888, second telegram. 
${ }^{65}$ PAR, ZA 6, enc. 3 in no. R937/88: Governor to General, 1 July 1888. PRO, WO 32/7838, file 079/6889: Havelock to Smyth, 1 July 1888, telegram.

${ }^{66}$ See the series of telegrams concerning operations that Havelock sent to Smyth during July and August 1888 in PRO, WO 32/7838, file 079/6889 and PRO, WO $32 / 7838$, file $079 / 6931$.

${ }^{67}$ PRO, WO 32/7838, file 079/6889: Smyth to Havelock, 16 July 1888 , telegram.

${ }^{68}$ PRO, WO 32/7838, file 079/6889: Havelock to Smyth, 16 July 1888, telegram.

${ }^{69}$ PRO, WO 32/7838, file 079/6889: Smyth to Stanhope, 17 July 1888, telegram.

${ }^{70}$ PRO, WO 32/7838, file 079/6901: Smyth to Havelock, 22 July 1888, telegram. PRO, WO 32/7838, file 079/6901 and file 079/6889: Havelock to Smyth, 23 July 1888, two telegrams. PRO, WO 32/7838, file 079/6889: Smyth to Havelock, 29 July 1888, telegram. PRO, WO 32/7838, file 079/6931: Smyth to Stanhope, 10 August 1888, telegram.

${ }^{71}$ PAR, GHZ 714, no. Z580/88: Smyth to Havelock, 21 August 1888; PAR, GHZ 716, no. Z767/88: Stabb to Assistant Military Secretary, 19 October 1888; Laband, Atlas ... op. cit., pp. 106-116.

72 This time there was to be no washing of linen in public as there had been regarding the disputes over divided command in the Cape in 1877-1878 and Natal in 1879, when the correspondence had been published in the British Parliamentary Papers and other Blue Books, and the Smyth-Havelock dispute was omitted from the published record.

73 PRO, WO 32/7838, file 079/6957: Ralph Thompson, War Office, to UnderSecretary of State at the Colonial Office, 1 November 1888.

${ }^{74}$ PRO, WO 32/7838, file 079/7062: Knutsford to Thompson, 4 January 1889. See also PRO, WO 32/7838, file 079/7099: Knutsford to War Office, 29 January 1889.

75 Coghlan, M. "The Natal Volunteers in the Anglo-Boer War, September 1899 to July 1902: Reality and perception”. PhD thesis, University of Natal, 2002, $13-32$.

${ }^{76}$ Laband, J. "Zulus and the War". In Gooch. J (ed), The Boer War: Direction, experience and image, London: Frank Cass, 2000, 119. 